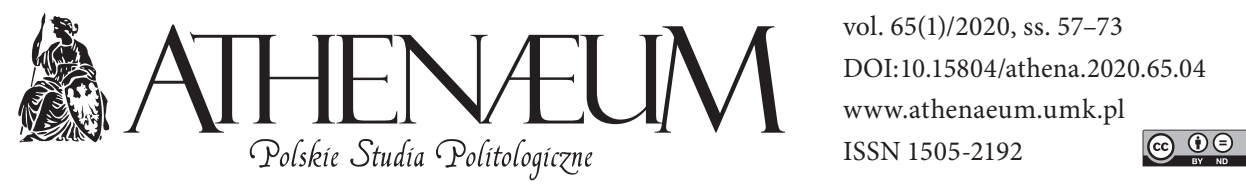

\title{
KRYTERIA ZGŁASZANIA KANDYDATÓW W WYBORACH W SYSTEMIE OCHRONY PRAW CZŁOWIEKA RADY EUROPY. ROZWAŻANIA NA KANWIE WYROKU ETPC TAHIROV PRZECIWKO AZERBEJDŻANOWI
}

\author{
CRITERIA FOR CANDIDATES' REGISTRATION IN ELECTIONS \\ IN THE COUNCIL OF EUROPE'S HUMAN RIGHTS \\ PROTECTION SYSTEM: \\ CONSIDERATIONS BASED ON THE ECHR JUDGMENT \\ TAHIROV VERSUS AZERBAIJAN \\ Marcin Jastrzębski*
}

\begin{abstract}
ABSTRAKT
Niniejszy artykuł zawiera szeroką analizę problemu kryteriów zgłaszania kandydatów w wyborach w systemie ochrony praw Rady Europy ze szczególnym uwzględnieniem wyroku Europejskiego Trybunału Praw Człowieka w sprawie Tahirov przeciwko Azerbejdżanowi. Podstawowe badania obejmą przede wszystkim orzecznictwo organów międzynarodowych chroniących prawa jednostki, ze szczególnym uwzględnieniem Europejskiego Trybunału i Komisji Praw Człowieka Rady Europy, oraz raporty misji obserwujących wybory OBWE.
\end{abstract}

Słowa kluczowe: Azerbejdżan; demokracja; prawa człowieka; prawo do wolnych wyborów; mandat parlamentarny; parlamentarzysta
This article contains extensive analysis of the problem of the criteria for nominating candidates in elections in the system of protection of the rights of the Council of Europe, with particular reference to the ECHR judgement Tahirov v. Azerbaijan. The basic research will mainly cover the jurisprudence of international bodies protecting individual rights, with particular emphasis on the European Court of Human Rights and the Council of Europe's Human Rights Commission, and reports from elections observation missions of the OSCE.

Keywords: Azerbaijan; democracy; human rights; right to free elections; parliamentary mandate; member of parliament

* Uniwersytet Kazimierza Wielkiego w Bydgoszczy, Wydział Nauk o Polityce i Administracji. 
Prawo do uczestnictwa w wolnych wyborach należy do kategorii podstawowych praw politycznych, jednoznacznie związanych $z$ demokratycznym reżimem politycznym. W skład tego uprawnienia wchodzą elementy organizacyjno-proceduralne (unormowanie samego procesu wyborczego, administracja wyborcza, warunki oddawania głosów, selekcja i desygnowanie kandydatów, obliczanie wyników wyborów itp.) oraz elementy podmiotowe - czynne i bierne prawo wyborcze. Oczywiście szczegółowe regulacje i praktyka usytuowana na płaszczyźnie podmiotowej wspomnianego prawa powinny tworzyć spójną całość z unormowaniem i praktycznym funkcjonowaniem warstwy instytucjonalno-formalnej.

Wyróżnienie poszczególnych elementów prawa do udziału w wolnych wyborach ma przede wszystkim charakter opisowy, porządkujący, a w praktyce granice tych płaszczyzn mogą być płynne. Możliwość kandydowania, zdobycia i późniejszego sprawowania mandatu - a więc skorzystania z biernego prawa wyborczego - jest poprzedzona zrealizowaniem szeregu procedur, których właściwe przeprowadzenie, przed uprawnionymi podmiotami, umożliwia kandydowanie i - po zdobyciu odpowiedniego poparcia - nabycie i sprawowanie stanowiska wybieralnego. Jedną $\mathrm{z}$ takich procedur, de facto rozpoczynającą korzystanie z biernego prawa wyborczego, jest tryb rejestrowania kandydatów lub list wyborczych.

Zasadniczym problemem badawczym analizowanym w niniejszym artykule jest odpowiedź na pytanie, jaki jest zakres marginesu swobody oceny wynikający z art. 3 Prot. 1 Europejskiej Konwencji Praw Człowieka (EKPC) dla państw będących jej stronami w określaniu wymogów rejestracyjnych dla kandydatów w wyborach. Szczegółowemu badaniu pod kątem zgodności ze standardem wolnych wyborów wyrażonym we wspomnianym protokole do Konwencji poddane zostaną procedury rejestracji kandydatur do zdobycia mandatu parlamentarnego w tytułowym wyroku Tahirov przeciwko Azerbejdżanowi i podobnych sprawach azerskich oraz w orzeczeniach Europejskiego Trybunału i Europejskiej Komisji Praw Człowieka (ETPC i EKomPC), dotyczących innych państw. Ze względu na ograniczenia objętości tej publikacji, analizie zostaną poddane wyroki i decyzje - zdaniem autora - kluczowe dla odtworzenia standardu rejestracji kandydatów w wyborach, wynikającego $\mathrm{z}$ art. 3 Prot. 1 do EKPC.

W niniejszej publikacji zastosowano przede wszystkim podejście instytucjonalne -opis mechanizmów funkcjonowania organów powołanych do ochrony postanowień EKPC w odniesieniu do tytułowej kwestii. Zasadniczą, przyjętą w omawianym artykule metodą badawczą jest metoda instytucjonalno-prawna, 
a podstawową techniką badawczą jest szczegółowa analiza orzeczeń ETPC i EkomPC związanych z przedmiotowym zagadnieniem.

$\mathrm{Na}$ początku niniejszego artykułu należy, w formie podstawowej, dokonać omówienia zasadniczych reguł ogólnych dotyczących biernego prawa wyborczego wynikających z prawa do wolnych wyborów wyrażonego art. 3 Prot. 1 do EKPC. Ich interpretacja dokonana w orzecznictwie strasburskim ma znaczący wpływ na szczegółową wykładnię procesu rejestracji kandydatów w wyborach.

\section{OGÓLNE ZASADY DOTYCZĄCE BIERNEGO PRAWA WYBORCZEGO W SYSTEMIE EKPC}

W precedensowym systemie ochrony Konwencji ostatecznym potwierdzeniem istnienia i zakresu ochrony konkretnych instytucji prawnych jest uwzględnienie tego faktu w orzecznictwie podmiotów stojących na straży przestrzegania regulacji zawartych w tym akcie normatywnym. W przypadku prawa do wolnych wyborów jurysprudencja EKomPC i ETPC pojawiła się stosunkowo późno, co wynikało również ze specyficznej, na tle innych praw i wolności zawartych w EKPC i protokołach dodatkowych, konstrukcji przepisu art. 3 Prot. I (Balcerzak, 2010, s. 459-461; Jasudowicz, 2011, s. 19-37; Garlicki, 2010, s. 566; Kamiński, 2015, s. 9-12; Schabas, s. 1029-1030). Co prawda pierwsze decyzje Komisji europejskiej dotyczące analizowanego przepisu zapadły w latach 60. XX wieku (EKomPC X. przeciwko Belgii, X. przeciwko Niemcom), jednak pierwszy wyrok ETPC w sprawie prawa do wolnych wyborów - w sprawie Mathieu-Mohin i Clerfayt przeciwko Belgii - ogłoszono dopiero w 1987 r.

Kwestia startu kandydatów w wyborach i ich uprzedniej rejestracji, logicznie rzecz biorąc, znajdowała się w zakresie art. 3 Prot. I do EKPC, co potwierdziły w formie ogólnego stwierdzenia zarówno Europejska Komisja, jak i Trybunał Praw Człowieka: organy te wielokrotnie uznawały, że art. 3 Protokołu nr 1 gwarantuje w szczególności „prawo do kandydowania w wyborach ustawodawczych, a po wyborze wykonywanie mandatu" (ETPC Mathieu-Mohin i Clerfayt, $\$ 51$; mutatis mutandis Masson; EKomPC M., s. 129). To prawo nie jest jednak uznawane za absolutne: państwa mogą narzucać na jego realizację szerokie ograniczenia. Zadaniem Trybunału jest zatem dopilnowanie, aby wspomniane ograniczenia nie doprowadziły w szczególności do uniemożliwienia „swobodnego wyrażania opinii ludzi na temat wyboru organu prawodawczego" (ETPC Mathieu-Mohin i Clerfayt, \$52). 
Prawo kandydowania jest warunkiem sine qua non podmiotowego aspektu prawa do wolnych wyborów - stanowi jeden z podstawowych elementów „rzeczywiście demokratycznego ustroju politycznego" wynikającego z art. 3 Prot. 1 do EKPC, będącego urzeczywistnieniem jednej z podstawowych wartości rekonstruowanych z preambuły Konwencji - zasady demokracji (ETPC Żdanoka, \$103). Jednocześnie Trybunał wielokrotnie powtarzał, że przedmiot i cel EKPC implikuje, aby jej postanowienia były interpretowane i stosowane zgodnie z zasadą efektywnej realizacji konwencyjnych praw i wolności, co oznacza, że gwarantuje ona „realne i efektywne, a nie teoretyczne i iluzoryczne” przestrzeganie tych swobód (ETPC Zjednoczona Komunistyczna Partia Turcji, $\$ 33$, Krasnov i Skuratov, $\$ 42)$.

Jednak już w pierwszym wyroku dotyczącym omawianego prawa ETPC przyznał państwom „szeroki margines oceny”, potwierdzając jednocześnie fakt, że nie ma ono charakteru absolutnego (ETPC Mathieu-Mohin i Clerfayt, $\$ 52$; Melnychenko, $\$ 59$ ). Wspomniany margines jest szerszy dla biernego prawa wyborczego niż w przypadku czynnego (ETPC Melnychenko, $\$$ 57; Żdanoka, § 115; Yumak i Sadak, \$109), co wynika z faktu, że to pierwsze oprócz zagwarantowania jednostkom możliwości dokonania wolnego wyboru - ma także zapewnić niezależność parlamentarzystów (ETPC Gitonas, \$39). Jednak głównym uzasadnieniem wspomnianego „szerokiego marginesu” jest przyznanie przez organy strasburskie w omawianym zakresie stronom EKPC „znacznej swobody” w ustalaniu konstytucyjnych ram regulujących bierne prawa wyborcze lub status deputowanego. Jest to reguła ogólna powtarzana we wszystkich orzeczeniach ETPC odnoszących się do biernego prawa wyborczego (np. ETPC Melnychenko, $₫ 55$; Żdanoka, $\$ 106$; Tanase, $\$ 156$; Garlicki, 2010, s.584-585).

Granice szerokiego marginesu oceny w przypadku biernego prawa wyborczego określone są przez regułę proporcjonalności, jednocześnie instytucje konwencyjne sprecyzowały tu szereg wymogów formalnych - przede wszystkim dotyczących stopnia określoności działań państwa wyznaczonego przez prawo krajowe i ich braku arbitralności (ETPC Podkolzina, $₫ 35$; Adamsons, $₫ 117$; por. Garlicki, 2010, s. 585; Zbrojewska, 2009, s. 214 i nast.). Obowiązek zapobieżenia arbitralności został pierwotnie sformułowany przez ETPC w związku z warunkami rejestracji kandydatów w wyborach, jednak następnie uznał, że jest on równie istotny we wszystkich sytuacjach, w których stawką jest skuteczność indywidualnych praw wyborczych (ETPC Namat Aliyev, $\$ 72$; mutatis mutandis: Kovach, \$55). 
Należy jednocześnie zaznaczyć, że ETPC szczególną ochronę przyznaje zarówno ogólnie w całym zakresie prawa do wolnych wyborów, jak i szczególnie w zakresie biernego prawa wyborczego, kandydatom i ugrupowaniom opozycyjnym (ETPC Tanase, $\$ 178-179)$. W tym kontekście istotne znaczenie ma zakaz dyskryminacji, wynikający z art. 14 EKPC (Por. ETPC Sejdić i Finci, $\$ 42$ i nast.). W związku z tym Trybunał podkreśla szczególne znaczenie wymogu nakazującego władzom odpowiedzialnym za administrację wyborczą działanie w sposób przejrzysty po to, by zachować ich bezstronność i niezależność od manipulacji politycznych (ETPC Namat Aliyev, \$73, Gruzińska Partia Pracy, \$101).

\section{DOTYCHCZASOWE ORZECZNICTWO ETPC DOTYCZĄCE ODMOWY LUB UCHYLENIA REJESTRACJI KANDYDATÓW LUB LIST WYBORCZYCH}

Tytułowe zagadnienie stało się przedmiotem orzecznictwa ad casum dopiero na przełomie w XX i XXI wieku. ETPC rozpatrzył już kilkadziesiąt skarg związanych z odmową wpisania bądź wykreśleniem $\mathrm{z}$ list wyborczych kandydatów lub stronnictw politycznych, uzasadnianą przez władze krajowe brakiem wypełnienia przez wspomniane podmioty pewnych formalnych warunków rejestracyjnych, takich jak wymogi podania określonych informacji czy złożenia różnorodnych oświadczeń lub dokumentów, które podlegają weryfikacji przez właściwe instytucje wyborcze.

Według Ireneusza Kamińskiego Trybunał strasburski, badając skargi związane z potencjalnym naruszeniem art. 3 Prot. 1 do EKPC poprzez brak rejestracji kandydata w wyborach, brał pod uwagę następujące kwestie:

a. czy skreślenie/niewpisanie na listę wyborczą następowało na podstawie określonych kryteriów i czy w związku z tym nie miało charakteru arbitralnego?;

b. czy jednostka/ugrupowanie polityczne rzetelnie spełniło wymogi rejestracyjne?;

c. czy w postępowaniu rejestracyjnym istniały obiektywne procedury odwoławcze? (Kamiński, 2015, s. 34)

Ad. a. „Prawo do kandydowania w wyborach, zagwarantowane w Artykule 3 Protokołu nr 1 i wpisane w ideę prawdziwie demokratycznych rządów, byłoby iluzoryczne, gdyby można było w dowolnym momencie zostać arbitralnie pozbawionym tego prawa. W związku z tym, o ile prawdą jest, że państwa dysponują 
szerokim marginesem uznania podczas określania warunków kandydowania in abstracto, zasada, że prawa muszą być skuteczne, wymaga ustalenia, że ten lub inny kandydat nie spełnił szeregu kryteriów sformułowanych ściśle, aby zapobiec arbitralnym decyzjom" (ETPC Russian Conservative Party of Entrepreneurs, $\$$ 50, Krasnov i Skuratov, $\$ 42$, Podkolzina, $\$ 35$, Melnychenko, $\$ 59)$. Tę zasadę ogólną Trybunał stosuje standardowo przy badaniu zgodności ze standardem konwencyjnym decyzji o niezarejestrowaniu kandydatów.

Przykładowo w sprawie Melnychenko przeciwko Ukrainie ETPC stwierdził, że ustawodawstwo i praktyka krajowa były niejasne - nie precyzowały wyraźnego wymogu „ciągłego” zamieszkiwania na Ukrainie i dodatkowo wymieniały wśród wymaganych dokumentów tylko wewnętrzny paszport jako jedyny dowód poświadczający miejsce zamieszkania. Kandydaci do parlamentu byli jedynie zobowiązani do przekazywania informacji w oparciu o ich propiskę - wewnętrzny paszport (Melnychenko, $\$ 59$ ).

W innym wyroku Trybunał zauważył, że definicja legalna kategorii osób prowadzących „profesjonalną aktywność religijną” była zbyt szeroka i nieprecyzyjna. Dodatkowo sposób zastosowania tego niejednoznacznego prawa wobec wnioskodawcy „doprowadził do sytuacji, w której istota praw zagwarantowanych w art. 3 protokołu nr 1 uległa osłabieniu” (ETPC Seyidzade, $\$ 39$ ).

Ad. b. Przyznając państwom szeroki margines swobody oceny w regulacji i praktyce rejestracji kandydatur wyborczych, sąd strasburski w zasadzie uznaje, że przyczynienie się skarżącego (np. poprzez podanie nieprawdziwych informacji czy naruszenie innych reguł) do podjęcia decyzji odmownej o wpisaniu go na listy wyborcze implikuje brak naruszenia art. 3 Prot. 1 do EKPC i odrzucenie skargi. Dotyczyło to m. in. jednostek, które naruszyły reguły finansowania kampanii wyborczej (ETPC Vitrenko), nawet jeśli decyzję o skreśleniu kandydata z listy kandydatów zapadła mniej niż 24 godziny przed dniem głosowania (ETPC Antonenko).

Należy jednak dodać, iż ETPC uznaje, że precyzyjnych wymogów dotyczących rejestracji kandydatów nie należy stosować zbyt rygorystycznie dla skarżących. W wyroku Krasnov i Skuratov przeciwko Rosji sąd strasburski dokonał rozróżnienia sytuacji obu skarżących. W przypadku pierwszego z nich, według ETPC, podał on nieprawdziwe informacje o miejscu zatrudnienia i pełnionej prominentnej funkcji (którą w międzyczasie przestał pełnić), co mogło zmylić jego elektorat (ETPC Krasnov i Skuratov, \$62). Natomiast w przypadku Skuratova komisja wyborcza zakwestionowała informację o zatrudnieniu na stanowisku dyrektora instytutu naukowego (kandydat przestał pełnić tę funkcję, ale był tam 
nadal zatrudnionym profesorem). ETPC uznał, iż w tym przypadku nie można było poważnie twierdzić, że różnica stanowisk profesora i pełnienie obowiązków szefa tego samego departamentu była w stanie wprowadzić w błąd wyborców, tym bardziej że „,zakwestionowany środek nie wydawał się spełniać wymaganego standardu "zgodności z prawem « i "przewidywalności«". Rzeczywiście w opinii niezależnych obserwatorów wyborów orzeczenie w sprawie jego wniosku „sugerowało niespójne i selektywne stosowanie zasad rejestracji” (ETPC Krasnov i Skuratov, $\$ 68)$.

Ad. c. W szeregu rozpatrywanych spraw Trybunał zauważył, że skarżącym nie przyznano wystarczających gwarancji proceduralnych chroniących przed arbitralnością administracji wyborczej wydającej decyzje o ich skreśleniu bądź niewpisaniu na listę kandydatów w wyborach. W szczególności dotyczyło to spraw azerskich. Zarówno centralna Komisja Wyborcza, jak i sądy, rozpatrując odwołania niezarejestrowanych kandydatów często nie informowały ich o rozprawach lub robiły to za późno, czy nie dopuszczając skarżących do konkretnych czynności, mimo iż byli oni uprawnieni do udziału w nich. Tym samym wymienione organy pozbawiały ich możliwości obrony swojego stanowiska a sobie uniemożliwiały kompleksową ocenę zaskarżonych sytuacji. Sądy krajowe często wręcz działały niezgodnie z prawem i nie udzielały uzasadnionej odpowiedzi na skargi (ETPC Atakishi, $₫ 48$; mutatis mutandis, Namat Aliyev, $\$ 90$, Orujov, $\$ 56)$.

W związku z tym konkluzja Trybunału co do przysługujących skarżącym w przedmiotowym zakresie środków odwoławczych wyglądała często następująco: „(...) ingerencja w prawa wyborcze skarżącego była niezgodna z normami wymaganymi na mocy Artykułu 3 Protokołu nr 1. W szczególności, wykluczenie skarżącego $\mathrm{z}$ kandydowania $\mathrm{w}$ wyborach nie było oparte na wystarczających i istotnych dowodach; procedury komisji wyborczej i sądów krajowych nie zapewniły skarżącemu wystarczających gwarancji przeciwko arbitralności, a decyzjom władz krajowych brakowało wystarczającego uzasadnienia i były one arbitralne" (ETPC Atakishi, $\$ 48$; Khanhuseyn, $\$ 42$; Abil, $\$ 40$ ).

Do czasu wydania tytułowego orzeczenia ETPC rozstrzygał pięć innych spraw „azerskich” dotyczących skreślenia z listy wyborczej kandydatów na parlamentarzystów. Wszystkie z nich dotyczyły poprzedniej elekcji parlamentarnej z listopada 2005 r. i we wszystkich Trybunał uznał naruszenie przez władze art. 3 Protokołu nr 1 do EKPC (Kamiński, 2015, s. 34-35).

Władze azerskie formułowały różne uzasadnienia do oskarżeń, które miały legitymizować wykreślenie kandydatów opozycyjnych z list wyborczych. Pierw- 
szemu z nich postawiono zarzut stosowania nieuczciwych metod zdobywania poparcia wyborców poprzez „kupowanie” głosów wyborczych. Z tym że zarzuty władz okazały się niespójne czy wręcz nielogiczne - co prawda kandydat sfinansował remont infrastruktury w swoim przyszłym okręgu wyborczym - jednak jego tożsamość jako fundatora tych inwestycji nie była powszechnie znana (ETPC Orujov).

Trzem kolejnym kandydatom zarzucono bezpośrednie kupowanie głosów wyborców poprzez rzekome wręczenie sum pieniężnych, jednak dowody przedstawione $\mathrm{w}$ tych sprawach nasuwały szereg wątpliwości, a podczas procedowania tych spraw przed organami wyborczymi nie zapewniono obwinionym kandydatom należytego w nich udziału, natomiast działanie władz miało charakter arbitralny - m.in nie przesłuchano świadków istotnych dla ewentualnego rozstrzygnięcia (ETPC Khanhuseyn; Abil; Atakishi).

Piąty z azerskich skarżących wraz z wnioskiem o rejestrację jego kandydatury w wyborach parlamentarnych złożył wymagane kodeksem wyborczym zobowiązanie o zakończeniu przez niego wszelkiej działalności zawodowej (w tym religijnej), niezgodnej z mandatem parlamentarnym. Następnie zrezygnował on ze stanowisk w Kaukaskiej Radzie Muzułmanów i Islamskim Uniwersytecie w Baku. Jednak komisja wyborcza unieważniła rejestrację jego kandydatury, uzasadniając to faktem kontynuowania przez niego „zawodowej działalności religijnej”. Stanowisko to podtrzymały Centralna Komisja Wyborcza i sądy krajowe.

Trybunał strasburski uznał, po raz kolejny, naruszenie art. 3 Protokołu nr 1 EKPC, co wynikało z niedostatecznej ścisłości przepisów krajowego kodeksu wyborczego. Regulacja nie określała, czy wymienione unormowanie skutkuje pozbawieniem biernego prawa wyborczego, czy też ustanawia zasadę incompatibilitas pewnych funkcji ze sprawowaniem mandatu parlamentarnego. Dodatkowo brak w kodeksie wyborczym jakiejkolwiek definicji terminów „duchowny” i „zawodowa działalność religijna” pozwolił władzom krajowym działać z nadmiernie dużą dowolnością i pozostawił wiele miejsca dla arbitralnego stosowania tego ograniczenia (ETPC Seyidzade).

ETPC w trzech innych sprawach również zakwestionował odmowę rejestracji kandydatów w wyborach parlamentarnych. Jedną z podstaw decyzji o naruszeniu art. 3 Protokołu nr 1 EKPC była różna praktyka władz krajowych i brak jednolitych i spójnych kryteriów w procesie rejestrowania przekształceń własnościowych, co w efekcie doprowadziło do arbitralnego zanegowania prawdziwości oświadczenia majątkowego kandydata i w konsekwencji skutkowało wykreśleniem go z list wyborczych (ETPC Sarukhanyan). 
Podobna sytuacja miała miejsce w kolejnej sprawie, która pojawiła się na wokandzie ETPC. Tym razem uchylono rejestrację list wyborczych partii politycznej po zakwestionowaniu prawdziwości oświadczeń majątkowych części kandydatów. Władze krajowe jako podstawę prawną swojej decyzji podały przepis przewidujący uchylenie rejestracji listy, gdy z wyborów wycofywał się jeden z trzech pierwszych kandydatów. Sąd rosyjski przyjął w niniejszej sprawie, w sposób arbitralny, szeroką interpretację wspomnianej normy, uznając, że wycofanie się kandydata jest tożsame $\mathrm{z}$ administracyjnym skreśleniem go $\mathrm{z}$ listy przez komisję wyborczą (ETPC Russian Conservative Party of Entrerpreneurs).

W ostatniej ze spraw dotyczących uchylenia rejestracji kandydatów ETPC orzekł niezgodność z art. 3 Protokołu nr 1 EKPC działań bułgarskiej Centralnej Komisji Wyborczej, która z powodu poważnych trudności praktycznych i prawnych wyzwań, które się przed nią pojawiły (związanych z uchwaleniem nowego prawa wyborczego na zaledwie 2 miesiące przed wyborami oraz dwoma wyrokami interpretacyjnymi Najwyższego Sądu Administracyjnego, które zostały wydane zaledwie na kilka dni przed wyborami), nie zdążyła na czas wykonać wyroku sądu krajowego uchylającego decyzję o skreśleniu skarżących z listy kandydatów (ETPC Petkov).

\section{WYROK ETPC W SPRAWIE TAHIROV PRZECIWKO AZERBEJDŻANOWI}

Tytułowa sprawa dotyczyła skargi o arbitralną odmowę rejestracji niezależnego kandydata w wyborach parlamentarnych w 2010 r. Było to 11 orzeczenie wydane przez ETPC przeciwko Azerbejdżanowi w sprawie naruszenia art. 3 Prot. 1 do EKPC (dotyczyły one poprzednich wyborów parlamentarnych z 2005 r.: Karimov; Atakishi; Abil; Khanhuseyn Aliyev; Hajili; Kerimli i Alibeyli; Mammadov (Nr 2); Kerimova; Namat Aliyev; Seyidzade). We wszystkich poprzednich wyrokach Trybunał uznał, że władze azerskie naruszyły prawo skarżących do udziału w wolnych wyborach, a dokładnie uniemożliwiły skorzystanie z biernego prawa wyborczego. Sześć z wymienionych spraw dotyczyło niezarejestrowania, $\mathrm{z}$ różnych powodów, kandydatur skarżących.

Skarżący zgłosił swoją kandydaturę w wyborach parlamentarnych w dniu 7 listopada 2010 r. Zgodnie z wymogami kodeksu wyborczego zebrał ponad 450 podpisów wyborców na poparcie swojej kandydatury i przekazał je Okręgowej Komisji Wyborczej. W dniu 11 października 2010 r. Tahirov został poinformo- 
wany, że ważność popierających go podpisów została już zbadana i że komisja wyborcza przeprowadziła przesłuchanie w sprawie rejestracji go jako kandydata. Następnego dnia odmówiono rejestracji jego kandydatury. Według eksperckiej grupy roboczej ustanowionej przez Komisję wiele podpisów było nieważnych, rzekomo z powodu złożenia kilku podpisów przez tę samą osobę lub z powodu niekompletności informacji na temat odpowiednich adresów wyborców.

Tahirov zaskarżył tę decyzję do Centralnej Komisji Wyborczej, twierdząc w szczególności, że zgodnie z wymogami kodeksu wyborczego powinien był zostać zaproszony do udziału w procesie oceny podpisów. Skarżący twierdził ponadto, iż ustalenie, że 172 podpisy zostały „wykonane przez tę samą osobę”, nie zostało zweryfikowane merytorycznie i że mógł skorygować niekompletne adresy niektórych $\mathrm{z}$ wyborców, gdyby miał taką możliwość. W załączeniu do skargi pan Tahirov przedłożył pisemne oświadczenia 91 wyborców, których podpisy zostały uznane za nieważne, potwierdzające autentyczność ich autografów.

Centralna Komisja przeprowadziła kolejną analizę kwestionowanych sygnatur. Została ona dokonana przez członków własnej grupy roboczej. Skarżący również nie został zaproszony do udziału w tym procesie. Wspomniana grupa potwierdziła, że 178 z 600 podpisów poparcia kandydatury Tahirova było nieważnych, a liczba pozostałych 422 ważnych podpisów była poniżej ustawowego minimum wynoszącego 450. W związku z tym Komisja Centralna oddaliła skargę Tahirova i utrzymała w mocy decyzję Komisji. Zarówno Sąd Apelacyjny w Baku, jak i Sąd Najwyższy - w dniu 2 listopada 2010 r. - odrzuciły apelację pana Tahirova jako nieuzasadnioną, bez szczegółowego zbadania jego argumentów (ETPC Tahirov, \$ 7-22).

Trybunał strasburski uznał, że wymóg odbioru 450 podpisów poparcia dla kandydata służył uzasadnionemu celowi zmniejszenia liczby kandydatów o minimalnych możliwościach wyboru. Następnie ETPC zbadał, czy procedura sprawdzania zgodności z przedstawionym powyżej wymogiem została przeprowadzona w sposób zapewniający wystarczające zabezpieczenie przed arbitralnością decyzji, zgodnie z kodeksem wyborczym w Azerbejdżanie.

Mimo że odmowa rejestracji kandydatury skarżącego - podobnie jak i wielu innych kandydatów - wynikała z ustaleń dotyczących rzekomej nieautentyczności podpisów popierających, rząd nie dostarczył konkretnych informacji o kwalifikacjach ekspertów grupy roboczej, którzy badali arkusze z podpisami wnioskodawcy. Eksperci ci doszli do wniosku, że istniało prawdopodobieństwo, że część podpisów było nieautentycznych. Jednakże nie zażądali dalszego 
dochodzenia, mimo że przepisy centralnego organu wyborczego dotyczące grup roboczych komisji wyborczych przewidywały możliwe, dodatkowe kroki w celu wyjaśnienia omawianej sytuacji. Trybunał uznał zatem, że wnioski komisji wyborczych były arbitralne. Konstatując, ETPC stwierdził więc, że pan Tahirov został pozbawiony możliwości zakwestionowania decyzji komisji wyborczej, która stwierdziła, że podpisy popierające jego kandydaturę nie były autentyczne.

Ponadto odpowiednie organy władze publicznej Azerbejdżanu nie przestrzegały żadnych gwarancji proceduralnych ustanowionych w Kodeksie Wyborczym dla ochrony przed arbitralnością postępowania, takich jak prawo kandydata do obecności podczas sprawdzania podpisów lub do odbioru sprawozdania z badania autentyczności podpisów przez grupę roboczą na 24 godziny przed posiedzeniem komisji wyborczej, właściwym dla zatwierdzenia wspomnianego raportu. Skarżący został w związku z tym pozbawiony możliwości kwestionowania ustaleń grup roboczych $\mathrm{w}$ trakcie całego procesu rejestracji jego kandydatury. Sytuacja ta, według raportu Organizacji Bezpieczeństwa i Współpracy w Europie (OBWE), nie dotyczyła tylko aplikanta, ale również co najmniej ponad 170 innych potencjalnych, niezarejestrowanych kandydatów w wyborach parlamentarnych $2010 \mathrm{r}$. W związku z tym wydawała się mieć charakter systemowy (OSCE/ODIHR Final Report, 2011). Ponadto ani azerska Centralna Komisja Wyborcza, ani sądy krajowe nie zajęły się żadnym z uzasadnionych argumentów przedstawionych przez skarżącego, ani, co gorsze, nie przedstawiły w swoich wyrokach właściwego uzasadnienia.

Trybunał ocenił, iż odmowa rejestracji kandydatury Tahirova była arbitralna i że procedura weryfikacji podpisów popierających jego kandydaturę została przeprowadzona w sposób, który nie zapewniał wystarczających gwarancji proceduralnych, skutkujących brakiem arbitralności postępowania, chociaż takie gwarancje zostały zapewnione przez kodeks wyborczy.

Jednym $\mathrm{z}$ argumentów rządu azerskiego przedstawionych w czasie rozprawy przed ETPC było stwierdzenie, że Kodeks wyborczy i inne regulacje zawierają dostateczne gwarancje rzetelnej weryfikacji podpisów popierających kandydatów. Trybunał skonstatował, iż „nie można poważnie twierdzić, że sam fakt, że prawa proceduralne zostały zawarte w kodeksie wyborczym, jest wystarczający, by zapobiec arbitralności. Rząd w swoich uwagach milczał na temat powtarzających się zarzutów skarżącego, że w niniejszej sprawie te przepisy Kodeksu wyborczego nie zostały faktycznie wdrożone w praktyce. (...) W tej kwestii Trybunał zauważa, że każda gwarancja zapisana w akcie prawnym jest 
bez znaczenia, jeżeli pozostaje tylko na papierze, tak jak wtedy, gdy właściwe organy krajowe, którym powierzono przeprowadzenie procedur wyborczych, systematycznie nie przestrzegają tych zabezpieczeń w sytuacjach, dla których zostały one zaprojektowane. Fundamentalnym następstwem rządów prawa jest stwierdzenie, że prawa zapisane w aktach ustawodawczych muszą być skuteczne i praktyczne, a nie teoretyczne i iluzoryczne" (ETPC Tahirov, \$66-67).

Trybunał uznał zatem, że postępowanie organów wyborczych, jak i sądów Azerbejdżanu ujawniło rażący brak prawdziwej troski o przestrzeganie praworządności i ochronę integralności wyborów oraz że panu Tahirovowi nie zapewniono wystarczających zabezpieczeń, aby zapobiec arbitralnej decyzji, odmawiając rejestracji jego osoby jako kandydata na parlamentarzystę. W konsekwencji doszło do naruszenia Artykułu 3 Protokołu nr 1 (ETPC Tahirov, $\$$ 70-72).

Trybunał strasburski powołał się również w uzasadnieniu wyroku na raport OBWE dotyczący wyborów parlamentarnych z dnia 7 listopada 2010 r. w Azerbejdżanie. Zgodnie z nim większość z 175 skarg otrzymanych przez Centralną Komisję Wyborczą kwestionujących decyzje odmowne o rejestracji kandydatów, dokonane przez lokalne komisje, zostało odrzuconych bez należytego rozpatrzenia. W związku z tym w analizowanym dokumencie znalazły się istotne wątpliwości co do bezstronności okręgowych komisji wyborczych, przejrzystości procesu rejestracji i odmowy rejestracji kandydatur w oparciu o drobne błędy techniczne (OSCE/ODIHR Final Report 2011).

Analizowane powyżej wyroki organów strasburskich w sprawach azerbejdżańskich są egzemplifikacją licznych nieprawidłowości, które pojawiają się w podczas wyborów przeprowadzanych w tym kraju. Potwierdzają one tezę o niedemokratycznym charakterze azerskiego systemu politycznego. Mimo że według postanowień konstytucji z 1995 r. (Konstytucja Republiki Azerbejdżanu z dnia 12 listopada 1995 roku; por. Brzeziński 2010:223) omawiane państwo jest teoretycznie demokratyczną republiką parlamentarną z prezydenckim systemem rządów (zob. szerzej Zaleśny, 2013; Siwiec, Baluk, 2007, s. 200-223; Heinrich, 2010, s. 10-25; Heinrich, 2011, s. 2-5), to jednak co najmniej od połowy lat 90. XX wieku, według opinii większości autorów analizujących system polityczny tego kraju, istniejący w Azerbejdżanie system rządów ma charakter „fasadowy” i jest w praktyce systemem hybrydowym lub wręcz autorytarnym (Siwiec, Baluk 2007, s. 2019, Brzeziński, 2010, s. 150-152; Heinrich, 2010, s. 12; Heinrich, 2011, s. 5; Meissner, 2011, s. 9; Cornell, 2001, s. 122-126) i opiera się na rządach klanu Alijewów (ojca Gejdara i syna Ilhama sprawujących kolejno funkcję prezydenta) 
i związanych z nimi ludzi (Brzeziński 2010, s. 150-152; Siwiec, Baluk, 2007, s. 204-208). Te opinie potwierdzone są również w licznych rankingach ustrojów państw (Zob. np. Freedom in the World 2019 i wcześniejsze, lub Democracy Index 2019 i wcześniejsze).

\section{PODSUMOWANIE}

Tytułowy wyrok w bazie HUDOC klasyfikowany jest jako tzw. orzeczenie powtarzające się (należy do licznej grupy decyzji sądowych z wiodącą sprawą Namat Aliyev). Z dwóch powodów jego znaczenie wydaje się być większe niżby wynikało to z przytoczonej kategoryzacji.

Po pierwsze wspomniane orzeczenie jest kolejnym, które uszczególawia obowiązki pozytywne państwa w zakresie przeprowadzenia wolnych wyborów $\mathrm{w}$ ich aspekcie instytucjonalno-proceduralnym i związanymi z nim formalnymi wymogami rejestracji kandydatów w wyborach (bierne prawo wyborcze). ETPC zaakceptował formułowany w prawie wyborczym większości państw stron konwencji wymóg zebrania przez kandydatów określonej liczby podpisów celem wyeliminowania kandydatur o minimalnych szansach wyboru. Uznał także wymaganą w prawie azerskim liczbę 450 sygnatur za rozsądną, zgodną z celem uprawionym art. 3 Prot. 1 do EKPC.

Sąd strasburski po raz kolejny podkreślił, że zadeklarowanie w aktach normatywnych jakichkolwiek uprawnień nie powoduje, że są one automatycznie przestrzegane. Także w kontekście różnorodnych procedur wyborczych, w tym rejestracji kandydatów, wymóg ich legalności jest pierwszorzędnym, ale nie jedynym warunkiem ich zgodności ze standardami konwencyjnymi. Strony konwencji, mimo że dysponują ,szerokim marginesem oceny” i dodatkowo „szeroką swobodą" kształtowania procedury rejestracji kandydatów, limitowane są w tym względzie obowiązkiem tworzenia prawa o wysokim stopniu określoności (aby w miarę możliwości wyeliminować działania arbitralne). Jednocześnie władze krajowe muszą działać w dobrej wierze, zmniejszającej możliwość podejmowania decyzji w sposób woluntarystyczny. Tak rygorystyczne sformułowanie w orzecznictwie strasburskim opisanych wyżej wymogów ma tym istotniejsze znaczenie, że procedura rejestracji kandydatów jest, obok sformułowania wymogów, jakie muszą oni spełnić (kwestia cenzusów wyborczych), etapem wstępnym ubiegania się o mandat parlamentarny, a więc stadium warunkującym skorzystanie $\mathrm{z}$ biernego prawa wyborczego w całym jego zakresie. 
Po drugie wyrok ten ma również znaczenie faktyczne - rozpoczyna ciąg orzeczeń dotyczących badania naruszeń biernego prawa wyborczego dokonanych przez władze azerskie podczas wyborów parlamentarnych w 2010 r. Wśród 13 wydanych dotychczas orzeczeń odnoszących się do tego problemu (wszystkie sprawy zostały przez Azerbejdżan przegrane), 7 dotyczyło dokładnie takiego samego sposobu eliminowania kandydatów - poprzez arbitralne, nieuzasadnione żadnymi dowodami negowanie prawdziwości podpisów zebranych przez kandydata (ETPC Bagirov; Vugar Aliyev; Gasimli; Soltanov; Mammadli; Gaya Aliyev. Pozostałe wyroki to: Annagi Hajibeyli; Gahramanli; Shukurov; Aslan Ismayilov; Samadbayli).

Łącznie we wspomnianych orzeczeniach poszkodowanymi było 26 niedoszłych kandydatów na parlamentarzystów (łącznie z Tahirovem, we wspomnianych 13 decyzjach sądowych było ogółem 51 ofiar naruszenia art. 3 Prot. 1 do EKPC). Świadczy to o sygnalizowanym, zarówno przez OBWE, jak i sam Trybunał strasburski, systemowym charakterze naruszeń prawa do wolnych wyborów w Azerbejdżanie. Pozwala to postawić pytanie, czy konwencyjna zasada „rzeczywiście demokratycznego ustroju politycznego" w tym kraju jeszcze funkcjonuje w minimalnym, zadowalającym zakresie. Problem ten nie dotyczy tylko tego państwa. Symptomatyczny zdaje się być fakt, że przeważająca większość orzeczeń ETPC stwierdzających naruszenie biernego prawa wyborczego dotyczy krajów powstałych z rozpadu ZSRR, wśród których Azerbejdżan wiedzie niewątpliwie prym w liczbie zarówno skierowanych przeciwko niemu, jak i przegranych przed Trybunałem spraw.

Przypadki nadużyć wyborczych w Azerbejdżanie i ich osądzenie przez ETPC pokazują również coraz mniejszą efektywność strasburskiego systemu ochrony praw człowieka (uznawanego za najskuteczniejszy z systemów międzynarodowych). Dzieje się tak przede wszystkim za sprawą państw postradzieckich, z których część, z Rosją na czele, zaczęła wręcz ostentacyjnie ignorować orzeczenia Trybunału. Niestety kolejne wybory odbywające się w Azerbejdżanie (Potocki, 2018) zdają się potwierdzać, iż państwo to podąża podobną drogą jak jego większy sąsiad.

BibLIOGRAFIA:

Balcerzak, M. (2010). Prawo do wolnych wyborów. W: B. Gronowska, T. Jasudowicz, M. Balcerzak, M. Lubiszewski, R. Mizerski (red.). Prawa człowieka $i$ ich ochrona. Toruń: Dom Organizatora. 
Baluk, W., Siwiec O. (2007). Republika Azerbejdżanu. W: W. Baluk, A. Czajowski (red.). Ustroje polityczne krajów Wspólnoty Niepodległych Państw. Wrocław: Wydawnictwo Uniwersytetu Wrocławskiego.

Brzeziński, M. (2010). Konstytucyjne podstawy bezpieczeństwa Republiki Azerbejdżanu. W: J. Zaleśny (red.). Zagadnienia ustrojowe państw poradzieckich, Warszawa: ELIPSA.

Cornell, S. E. (2001). Democratization falters in Azerbaijan. Journal of Democracy, 12 (2).

Decyzja EKomPC X. p. Niemcom z 6.10.1967 r., nr skargi 2728/66, YB, t. 10.

Decyzja EKomPC M. p. Zjednoczonemu Królestwu z 7.03.1984 r., nr skargi10316/83, DR37.

Decyzja EKomPC X. p. Belgii z 18.09.1961 r., nr skargi 1028/61, YB, t. 4.

Decyzja ETPC w sprawie Vitrenko i inni p. Ukrainie z 16.12.2008 r., nr skargi 23510/02.

Democracy Index 2018. Pobrane z: https://www.eiu.com/public/topical_report. aspx?campaignid=Democracy2018.

Garlicki, L. (2010). [Protokół I], Art. 3. Prawo do wolnych wyborów. W: L. Garlicki (red.). Konwencja o Ochronie Praw Człowieka i Podstawowych Wolności. Tom II. Komentarz do artykułów 19-59 i Protokołów dodatkowych. Warszawa: Beck.

Heinrich, A. (2010). The formal political system in Azerbaijan and Kazakhstan: a background study. Pobrane z: https://nbn-resolving.org/urn:nbn:de:0168-ssoar-441356.

Heinrich, A. (2011). The Formal Political System in Azerbaijan. Caucasus Analytical Digest, 24.

Jasudowicz, T. (2011). Prawo do wolnych wyborów w byłych europejskich państwach socjalistycznych. Polski Rocznik Praw Człowieka i Prawa Humanitarnego, 2.

Kamiński, I. (2015). Prawo do wolnych wyborów w Europejskiej Konwencji Praw Człowieka. Problemy Współczesnego Prawa Międzynarodowego, Europejskiego i Porównawczego, XIII.

Konwencja O Ochronie Praw Człowieka i Podstawowych Wolności, przyjęta 4.11.1950 r., Dz. U. 1993, Nr 61 poz. 284.

Postanowienie ETPC Masson p. Francji z 14.09.1999 r., nr skargi 41944/98.

Potocki, M. (2018). Jak sfałszować wybory? Środowe manipulacje w Azerbejdżanie świetnie to ilustrują. Pobrane z: https://wiadomosci.dziennik.pl/opinie/artykuly/572552,wybory-prezydent-azerbejdzan-falszerstwo-analiza-matematyka.html.

Raport Freedom in the World 2019. Pobrane z: https://freedomhouse.org/report/ freedom-world/2019/azerbaijan.

Schabas. W. (2015). The European Convention on Human Rights: A Commentary. Oxford: Oxford University Press.

The Organisation for Security i Cooperation in Europe, Office for Democratic Institutions i Human Rights (OSCE/ODIHR), Election Observation Mission, Final Report on the Parliamentary Elections of 7 November 2010 (Warsaw, 25 January 2011).

Wyrok ETPC Abil p. Azerbejdżanowi z 21.02.2012 r., nr skargi 16511/06.

Wyrok ETPC Adamsons p. Łotwie z 24.6.2008 r., nr skargi 3669/03.

Wyrok ETPC Annagi Hajibeyli p. Azerbejdżanowi z 22.10.2015 r., nr skargi 2204/11. 
Wyrok ETPC Antonenko p. Rosji z 23.05.2006 r., nr skargi 42482/02.

Wyrok ETPC Aslan Ismayilov i Inni p. Azerbejdżanowi z 13.04.2017 r., nr skargi 20411/11 20443/11 24070/11.

Wyrok ETPC Atakishi p. Azerbejdżanowi z 28.02.2012 r., nr skargi 18469/06.

Wyrok ETPC Bagirov i Inni p. Azerbejdżanowi z 17.12.2015 r., nr skargi 17356/11 30504/11 31959/11.

Wyrok ETPC Gahramanli i Inni p. Azerbejdżanowi z 8.10.2015 r., nr skargi 36503/11. Wyrok ETPC Gasimli i Inni p. Azerbejdżanowi z 17.12.2015 r., nr skargi 25330/11 25340/11 25345/11.

Wyrok ETPC Gaya Aliyev i Inni p. Azerbejdżanowi z 16.06.2016 r., nr skargi 29781/11 29808/11 30372/11.

Wyrok ETPC Gitonas p. Grecji z 1.7.1997 r., nr skargi 18747/91, 19376/92, 19379/92, 28208/95 i 27755/95.

Wyrok ETPC Gruzińska Partia Pracy p. Gruzji z 8.07. 2008 r., nr skargi 9103/04.

Wyrok ETPC Hajili p. Azerbejdżanowi z 10.01.2012 r., nr skargi 6984/06.

Wyrok ETPC Karimov p. Azerbejdżanowi z 25.09.2014 r., nr skargi 12535/06.

Wyrok ETPC Kerimli i Alibeyli p. Azerbejdżanowi z 10.01.2012 r., nr skargi 18475/06 22444/06.

Wyrok ETPC Kerimova p. Azerbejdżanowi z 30.09.2010 r., nr skargi 20799/06.

Wyrok ETPC Khanhuseyn Aliyev p. Azerbejdżanowi z 21.02.2012 r., nr skargi 19554/06, Wyrok ETPC Khanhuseyn p. Azerbejdżanowi z 21.02.2012 r., nr skargi 19554/06.

Wyrok ETPC Kovach p. Ukrainie z 7.02.2008 r., nr skargi 39424/02.

Wyrok ETPC Krasnov i Skuratov p. Rosji z 19.07.2007, nr skargi 17864/04.

Wyrok ETPC Mammadli i Inni p. Azerbejdżanowi z 30.06.2016 r., nr skargi 2326/11 8055/11 25355/11.

Wyrok ETPC Mammadov p. Azerbejdżanowi (Nr 2) z 10.01.2012 r., nr skargi 4641/06. Wyrok ETPC Mathieu-Mohin i Clerfayt p. Belgii z 2.03.1987 r. , nr skargi 9267/81.

Wyrok ETPC Melnychenko p. Ukrainie z 19.10.2004 r., nr skargi 17707/02.

Wyrok ETPC Namat Aliyev p. Azerbejdżanowi z 8.04.2010 r., nr skargi 18705/06.

Wyrok ETPC Podkolzina p. Łotwie z 9.04.2002 r., nr skargi 46726/99.

Wyrok ETPC Russian Conservative Party of Entrepreneurs i inni p. Rosji z 11.01.2007 r., nr skargi 55066/00 i 55638/00.

Wyrok ETPC Samadbayli i Inni p. Azerbejdżanowi z 13.04.2017 r., nr skargi 36821/11 37656/11 37661/11.

Wyrok ETPC Sejdić i Finci p. Bośni i Hercegowinie z 22.12.2009 r., nr skargi 27996/06 i $34836 / 06$.

Wyrok ETPC Seyidzade p. Azerbejdżanowi z 3.12.2009 r., nr skargi 37700/05.

Wyrok ETPC Shukurov p. Azerbejdżanowi z 27.10.2016 r., nr skargi 37614/11.

Wyrok ETPC Soltanov i Inni p. Azerbejdżanowi z 16.06.2016 r., nr skargi 30362/11 30581/11 30728/11.

Wyrok ETPC Tahirov p. Azerbejdżanowi z 11.06.2015 r., nr skargi 31953/11.

Wyrok ETPC Tanase p. Mołdawii z 19.11.2008 r., nr skargi 7/08. 
Wyrok ETPC Vugar Aliyev i Inni p. Azerbejdżanowi z 17.12.2015 r., nr skargi 24853/11 28465/11 28502/11.

Wyrok ETPC w sprawie Orujov p. Azerbejdżanowi z 26.07.2011 r., nr skargi 4508/06, Wyrok ETPC w sprawie Petkov i inni p. Bułgarii z 11.06.2009 r., nr skargi 77568/01. Wyrok ETPC w sprawie Sarukhanyan p. Armenii z 27.05.2008 r., nr skargi 38978/03. Wyrok ETPC w sprawie Seyidzade p. Azerbejdżanowi z 9.12.2009 r., nr skargi 37000/05. Wyrok ETPC w sprawie Żdanoka p. Łotwie z 16.03.2006 r., nr skargi 58278/00.

Wyrok ETPC Yumak i Sadak p. Turcji z 8.07.2008 r., nr skargi 10226/03.

Wyrok ETPC Zjednoczona Komunistyczna Partia Turcji i Inni p. Turcji z 30.01.1998 r., nr skargi19392/92.

Zbrojewska M. (2009). Glosa do wyroku ETPCz z dnia 24 czerwca 2008 r. w sprawie Adamsons p. Łotwie (nr skargi 3669/03), Przeglad Sejmowy, 3. 